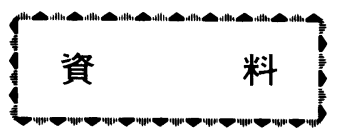

\title{
光源材料における表面・界面の諸問題 ${ }^{\dagger}$
}

\author{
専門会員 渡部勁二*
}

\section{1.まえがき}

1879 年にエジソンがカーボンフィラメントを使った白 熱電球を発明して以来, 光源の歷史は材料の発達史でもあ った. 効率, 演色性, 光色，寿命などの性能向上を目的 に，種々の材料が開発され，適用されてきたが，乙のなか で材料の表面の性質が光源の性能と深い係わりを持ってい る. 吸着・脱離, 女れ, 接着, 洗浄, 蒸発, スパッタリン グ, 電子放射, 二次電子放射, 腐蝕・防蝕, メッキ, 粉体 焼結, 薄膜, ガス放出など多方面にわたる表面現象がいろ レろな形で研究課題となってきた，表面を扱らととは“泥 沼に入る”と言われ，試行錯誤のくり返えし，実験条件に よって得られるデータがばらつくなど苦労が多い.しかし 最近の表面解析装置の発展や分析手法の進歩により, 表面 の構造, 組成, 化学状態を精密に知るととができるよらに なり, 各方面の研究が盛んになってきた. 平成元年 3 月に 開催された照明学会光関連材料・デバイス研究専門部会主 催の公開研究会「光源材料一表面その他の特性」には多数 の参加者があり，関心の高さが示されたものと言えよう.

本報では，各種光源材料と表面との係わり，課題につい て概説する。

\section{2. 光源材料と表面現象}

表 1 亿主要な光源材料, ガラス・セラミックス, 蛍光 体, 電子放射材料, 金属材料, 封入材料, ゲッタとてれら に関わる表面現象をまとめた，以下，乙れらのらちトピッ クス的なものについて個々に述べるととにする.

\section{1 ガラス・セラミックス}

ランプ用ガラスでは，加工が容易なとと，熱衝撃性に強 らこと, 電気抵抗が大きいこと, 光の透過率がよいとと, 機械的強度が大きいとと, 化学的耐久性が大きいとと, 安 価であるととなどが求められる. 白熱電球, 䖢光ランプで はソーダライムガラスがバルブに，鉛ガラスがステムに使 われる. これらのガラスはランプ製造プロセスで, 洗浄, ベークアウトを行い，ガラスの表面の污れや吸蔵ガスを取

† Various problems about surfaces and interfaces of light source materials

* 三菱電機怢生活システム研究所

Keiji Watanabe
表 1 光源材料と表面現象

\begin{tabular}{|c|c|c|c|c|c|c|c|}
\hline & 光 源 & 材 料 & & 表 & 面 & 現 & 象 \\
\hline \multicolumn{4}{|c|}{ ガラス・セラミックス } & \multicolumn{4}{|c|}{$\begin{array}{l}\text { ○封着における金属とのぬれ } \\
\text { ○ガス放出 } \\
\text { ○表面変貝 } \\
\text { 。表面処理 } \\
\text { ○封入材料との反応 } \\
\text { ○イオンの侵入 } \\
\text { ○紫外線による表面層の収縮 }\end{array}$} \\
\hline 蛍 & 光 & & 体 & \multicolumn{4}{|c|}{$\begin{array}{l}\text { ○水銀吸着 } \\
\circ \mathrm{Hg}^{+}, \mathrm{Ar}^{+} \text {などのイオン衝撃 } \\
\text { ○ガラスバルブとの反応 } \\
\text { ○ガス吸着 } \\
\text { ○表面層の欠宿による紫外線の吸収 }\end{array}$} \\
\hline 電 & 乙 放 & 射 材 & 料 & \multicolumn{4}{|c|}{$\begin{array}{l}\text { ○熱電子放射 } \\
\text { ○二次電子放射 } \\
\text { ○蒸発 } \\
\circ \text { スパッタリング } \\
\circ \text { ○゙ス吸着 } \\
\text { ○ガス放出 } \\
\text { ○表面拡散 } \\
\text { 。封入材料との反伈 }\end{array}$} \\
\hline 金 & 属 & 材 & 料 & \multicolumn{4}{|c|}{$\begin{array}{l}\text { ○蒸発 } \\
\text { ○スパッタリング } \\
\text { ○表面拡散 } \\
\text { ○ガス放出 } \\
\text { ○封入材料との反応 } \\
\text { ○ガス吸着 } \\
\text { ○ぬれ } \\
\text { ○表面処理 }\end{array}$} \\
\hline 封 & 入 & 材 & 料 & $\begin{array}{l}\text { ○ガス吸着 } \\
\text { ○ガス放出 } \\
\text { ○ガラス, }\end{array}$ & V & , & 上の反応 \\
\hline ゲ & . & & 夕 & ○ガス吸着 & & & \\
\hline
\end{tabular}

り除くことが行われる.ガラス中には溶融状態のとき気体 がとけとんでいる。 また，ガラス表面に吸着している気体 は主に水分である，ガラスをべークすると，一般に $200{ }^{\circ} \mathrm{C}$ までに放出がスのピークがあらわれるが，とれは表面吸 着の水であり，さらに昇温するとガラス内部より水が放出 される。この水の放出は搪散律速であると言われている が1)，内部の水分を完全飞除去するのは難しい，従ってラ ンプバルブとしては水分を含有しないものが望ましいが, 特にメタルハライドランプに使われる石英ガラスについて 


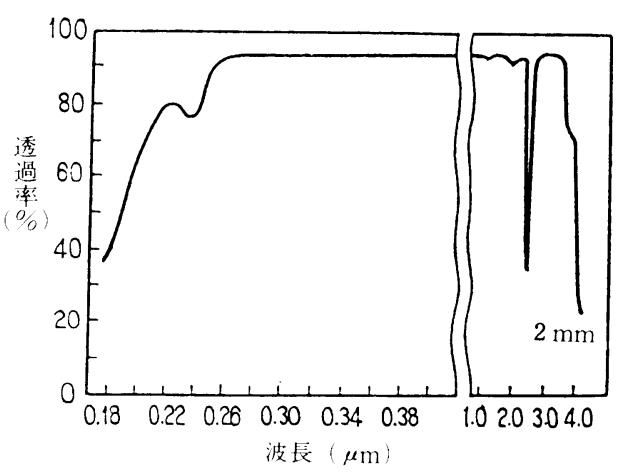

(a)

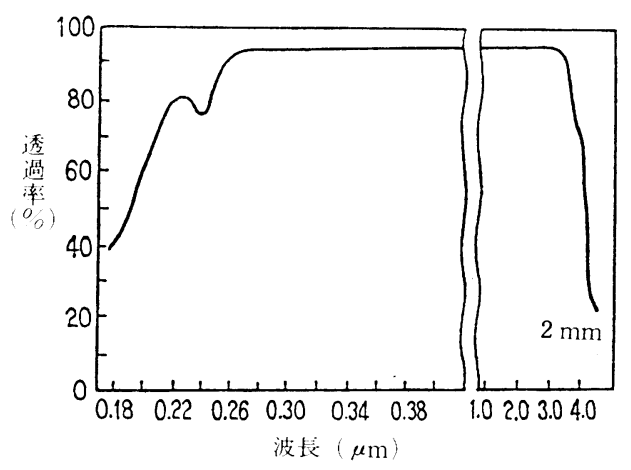

(b)

図 1 透明石英ガラスの透過率 ${ }^{2)}$

(a) 火炎溶融（ベルヌイ法）

(b) 真空溶融法

は水分フリーが必要である，石英ガラス中に水分が存在す ると, ランプ点灯中に発光管内に放出され, 黒化, 始動不 良となり, 短寿命となる. 図 1 亿火炎溶融と真空溶融法に よる透明石英ガラスの分光透過率を示す. 火炎溶融法によ るものは, $1.4 \mu \mathrm{m}, 2.2 \mu \mathrm{m}, 2.7 \mu \mathrm{m}$ に OH 基による吸収が あるが，真空溶融法では $\mathrm{OH}$ 基は $5 \mathrm{ppm}$ 以下となる ${ }^{2)}$. メタルハライドランプではこの真空溶融法による石英ガラ スを使用し，さらにふっ酸で表面を除を， $1000{ }^{\circ} \mathrm{C}$ 程度の 熱処理を行ら.

ステムには電力導入用ジュメット線が封着される・ジュ メット線は $58 \%$ 鉄一 $42 \%$ ニッケル合金の心線に銅を被覆 したものであるが，ガラスとの界面で強い接着強度をも たせるため, 酸化処理を行い, 薄い酸化銅膜層を形成し, これがガラスとの拡散層を形成し，接着強度を高めてい $ろ^{3)}$. 酸化膜が厚すぎると, 金属との接着強度が下り， あ るいは膜内に亀裂ができ，リークの原因になる。

高圧ナトリウムランプの発光管には透光性多結晶アルミ ナが使われ, 真空気密は封着金属ニオブと封着ガラス $\mathrm{Al}_{2} \mathrm{O}_{3}-\mathrm{CaO}$ 系ガラスで保たれる.とれらの材料は互いに 熱膨張係数が似ている上に, 封着界面に中間層が形成され るので強固に密着している。すなわち, 図 2 のシール部の XMA ラインプロファイルに示されるよ5に, 多結晶アル

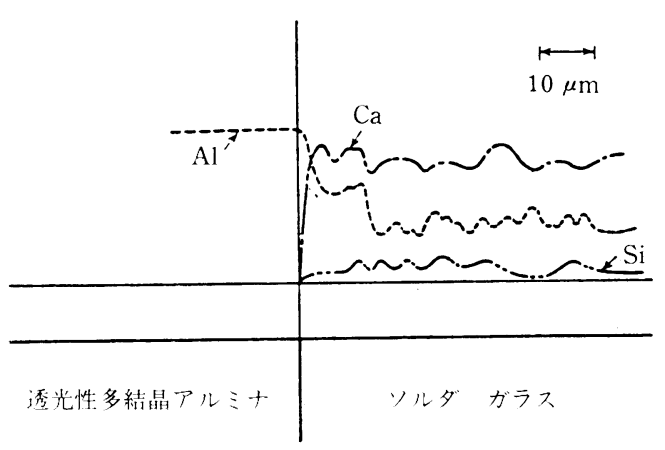

(a)

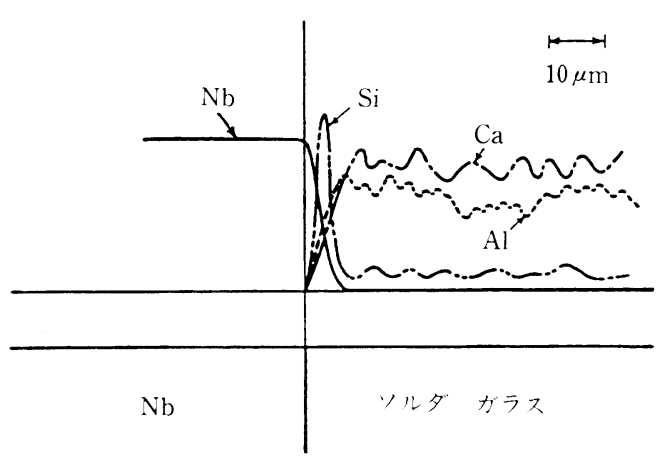

(b)

図 2 シール部のXMA ラインプロファイル4)

(a) 多結晶アルミナとソルダガラス

(b) Nbとソルダガラス

ミナが封着ガラス側へ溶出，またニオブ表面が酸化され， 酸化ニオブとして封着ガラスへ溶出, 適切な厚さの中間層 を形成するてとで，気密端子の機械的性質が高くなってい $ろ^{4)}$.

ガラスの特性改良を目的として, 各種の表面処理が行わ れる. ガラスの表面でのイオン交換による化学強化, ステ 一ニング着色, 屈折率分布ガラスが実用され, さらに選択 的エッチングによる拡散膜, 反射防止膜の生成, 耐候性向 上が行われている. また, 蒸着法, ゾルゲル法, CVD法 などのコーティングにより多層膜の生成を行い, 着色, 反 射，屈折などの光学的特性の改良を行らとともに，機械的 強度 (表面硬度) の向上対策として応用される ${ }^{5)}$.

\section{2 巣光体}

ランプ用蛍光体は，254nm の紫外線で主に励起される が，蛍光ランプでは $185 \mathrm{~nm}$ の紫外線, 高圧水銀ランプで は $313 \mathrm{~nm}$ および $365 \mathrm{~nm}$ の紫外光による励起も無視でき ない. 励起過程は母体結晶構造と付活剤イオンの配置によ って决まり, 表面が関与する程度は小さいが, 蛍光体原材 料の粒形, 粒度, 焼成後の粉砕などが初期輝度に影響す る. 蛍光ランプの蛍光体としては $\mathrm{Sb}^{+3}$ と $\mathrm{Mn}^{+2}$ で付活さ れたハロリン酸カルシウム $\mathrm{Ca}_{5}\left(\mathrm{PO}_{4}\right)_{3}(\mathrm{~F}, \mathrm{Cl}): \mathrm{Sb}^{+3}, \mathrm{Mn}^{+2}$ の白色蛍光体が典型的である. この䖵光体を用いた蛍光ラ ンプは点灯初期若干の光束低下がある. 原因は管内の 185 
$\mathrm{nm}$ 紫外光の照射によって，䖢光体にカラーセンタ一が生 成され，励起光の一部を吸収するためとされている ${ }^{6)}$ 。 た長時間点灯した蛍光膜は少し黒ずんで見える.てれは水 銀，または水銀の化合物の吸着である。交拉，水銀が単に 弱く吸着しているといらょりも Si-Oのグループに直接結 合したためといら報告もある. またソーダライムガラスで は, 点灯中にナトリウムが溶出して蛍光体膜中一拡散し, 発光效率の低下をひをおこすと言われている77.

\section{3 電子放射材料}

蛍光ランプでは, タングステンコイルに $\mathrm{Ba}, \mathrm{Sr}, \mathrm{Ca}$ の 酸化物を主体とする電子放射材料が塗布され，また HID ランプではタングステン心線のまわりにタングステンコイ ルを巻き，コイルの表面あるいは間吵に電子放射材料を塗 布する. ランプ点灯中, 電極が陰極となる周期で電子が放 出される．陰極周期には電極上に放電のスポットができ， 熱電子放射が行われる。乙の熱電子放射は，リチャードソ ン・ダッシュマンの式, すなわち

$$
\begin{aligned}
I= & \mathrm{A} T^{2} \exp (-e \phi / k T) \\
& \mathrm{A}: \text { リ リャードソン定数 } \\
& \phi: \text { 仕事関数 }
\end{aligned}
$$

により表わされる. 電子放射量は仕事関数 $\phi$ に依存する が, 現実の営光ランプの電極や HID ランプの電極で放電 スポットにおける仕事関数を决めることは困難である. 夕 ングステンコイル上に塗布された電子放射材料から解離し た Ba 原子が放電スポット点まで表面抎散で移動してくる が，スポットの温度で蒸発してしま5。すなわち，放電ス ポットでは Ba 原子は吸着一脱離平衡になっている ${ }^{8)}$. し たがって, Ba 原子の供給が多いと蒸発が増加し, ランプ の管壁黒化につながる. 電子放射材料からの Ba 原子の供 給は，電子放射材料の蒸発速度と関係がある，蒸発速度の 異なる電子放射材料を高圧水銀ランプの電極に使用し，蒸 発速度が光束劣化を左右することが報告されている ${ }^{9)}$.

電子放射材料の仕事関数は，またランプの放電開始電压 に関係する. 気体の压力を $P$, 電極間距離を $d$ とすると, タウンゼント機構にもとづく放電開始電压 $V_{S}$ は,

$V_{S}=\mathrm{B} \cdot P \cdot d /\{\ln \mathrm{A} \cdot P \cdot d-\ln \ln (1+1 / r)\}$

$\mathrm{A}, \mathrm{B}$ : 気体の種類によって决まる定数

と表わせる. 仕事関数は二次電子放出係数 $r$ に含まれてい る.図 3 は，あらかじめ仕事関数を測定した電子放射材料 を高压水銀ランプ用電極に塗布し，アルゴンガス中で放電 開始電压を測定した結果である ${ }^{9)}$. $V_{S}$ の仕事関数低存性 があらわれている．放電開始電圧より高い電压が印加され ると，放電はグロー放電となり，イオン衝撃で陰極が加熱 され，熱電子放射量がイオンによるr電子放出量より多く なると，グロ一放電からアーク放電に移行する。したがっ て仕事関数が低く, 熱電子放射が容易な電極ほど, グロー ・アーク移転がすみやかとなる．ランプの電極の特性評価 の上で，グロー・アーク転移も重要な項目である ${ }^{10,11)}$.

このよ5に仕事関数は, 放電開始や放電維持に深く係わ っているが，現実のランプの電極で仕事関数の值がどのよ

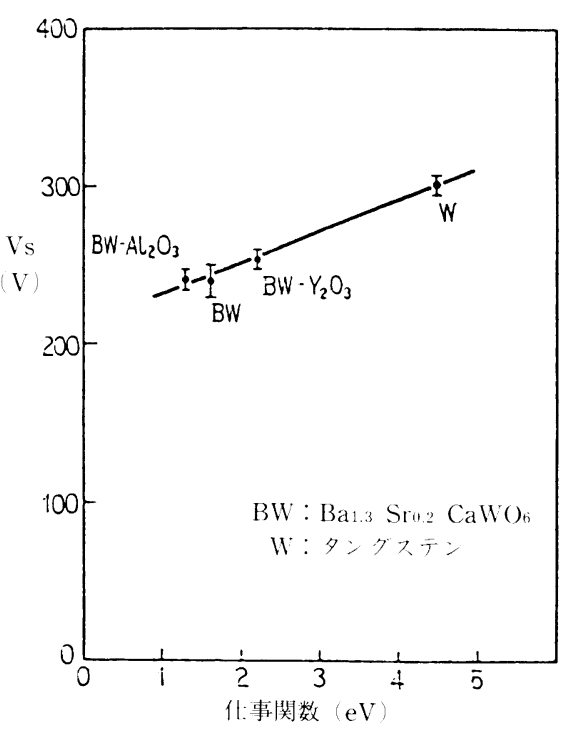

図 3 電子放射材料の仕事関数之Ar 放電開始電 $1^{-9)}$ $(\mathrm{P} \cdot \mathrm{d}=0.6)$

らになっているかを述べるのはむずかしい，その第一の原 因は，先にも述べたよらに，放電のスポットでは電子放射 活性物質（例えば $\mathrm{Ba}$ ）が吸着一脱離平衡になっており， 刻々の変化のため測定がむずかしい点にある。第 2 に，ラ ンプの発光管内には $\mathrm{H}_{2} \mathrm{O}, \mathrm{H}_{2}, \mathrm{CO}, \mathrm{CO}_{2}$ など多くの不純 ガスが存在し，てれらが電極沉吸着し，表面を複雑にして らる. メタルハライドランプには, 電気陰性度の高いハロ ゲン化物が封入されているので，現象は一首複雑である. タングステン表面へのよう化ナトリウムと水銀, 酸素, 水 分, 水素との複合吸着が電界放出型顕微鏡で研究され ${ }^{12)}$, 吸着状態でタングステンの仕事関数より高くなったり，低 くなったりすることが示され，大変興味深い.

メタルハライドランプの電子放射物所としては, 発光管 内にハロゲン化物が存在するために，アルカリ土類金属酸 化物が使用できない。そこでトリウム，酸化トリウム，希 土類金属酸化物が使われる. 希土類金属酸化物は, 発光物 質として希上類金属八ロゲン化物を封人したランプに適し ている．Dy-Tlのよら化物を封人したランプでは $\mathrm{Dy}_{2} \mathrm{O}_{3}$ を， $\mathrm{Na}-\mathrm{Sc}$ のよら化物を封入したランプでは $\mathrm{Sc}_{2} \mathrm{O}_{3}$ を用い る. 発光物質之同じ希土類の酸化物を使用し，発光物質の 八ロゲン化物之電子放射物質との化学反応を防止するため である ${ }^{13)}$. しかしながら，乙れらの材料の仕事関数がアル カリ七類金属酸化物より高いために，放電開始電小が必然 的に高くなり, 高压水銀ランプに比較し, メタルハライド ランプでは始動に関係する課題が多い原因のもとをなして いる.

メタルハライドランプでは, 発光管の石英と電極, およ び封入物との間の化学反応が大きな課題である. この反応 に関しては，従来から報告があるが，まだ解明される心゙き ことが多い，反応モデルは Speros，D．M．らによるもの が代表的であり，以下のようである ${ }^{14)}$.

$\mathrm{MX}_{3}=\mathrm{M}+3 \mathrm{X}$ 


$$
\begin{aligned}
& \mathrm{M}+n \mathrm{SiO}_{2}=\mathrm{MxOy} \cdot m \mathrm{SiO}_{2}+\mathrm{SiO} . \\
& 2 \mathrm{SiO}=\mathrm{SiO}_{2}+\mathrm{Si} \ldots \ldots \ldots \ldots \ldots \ldots \ldots \ldots \ldots \ldots \ldots \ldots \ldots \ldots \ldots \ldots \ldots \ldots \\
& \mathrm{Si}+4 \mathrm{X}=\mathrm{SiX}_{4} \ldots \ldots \ldots \ldots \ldots \ldots
\end{aligned}
$$

ことでM，Xはそれぞれ金属とハロゲン元素である. $\mathrm{ScI}_{3}$ が発光管に封入されているとき, 反応(1)(2)(3)(4)をまとめて 表わすと,

$$
4 \mathrm{ScI}_{3}+7 \mathrm{SiO}_{2}=2 \mathrm{Sc}_{2} \mathrm{Si}_{2} \mathrm{O}_{7}+3 \mathrm{SiI}_{4}
$$

となる、実際のランプで $\mathrm{Sc}_{2} \mathrm{Si}_{2} \mathrm{O}_{7}$ を同定するととは難しい が，石英と $\mathrm{ScI}_{3}$ の反応のモデル実験から $\mathrm{Sc}_{2} \mathrm{Si}_{2} \mathrm{O}_{7}$ が検出 されたととが報告されている ${ }^{15)}$. しかし一方， $\mathrm{ScI}_{3}$ と石英 との反応に関しては次のような反応も提案されている ${ }^{16)}$.

$$
2 \mathrm{ScI}_{3}+\mathrm{SiO}_{2}=2 \mathrm{ScOI}+\mathrm{SiI}_{4}
$$

上記反応式(2)で生成された $\mathrm{SiO}$ は発光管内の他の場所 で, 反応式(3)により $\mathrm{SiO}_{2}$ となり, 球状の堆積物を生じ $ろ^{14)}$.

Dy-Tlのよら化物を封入したランプでも同じょらに $\mathrm{SiO}_{2}$ の球状堆積物 ${ }^{17)}$ や白色粉末の付着 ${ }^{18)}$ が見られている が，上記反応式(5)や(6)のよらな silicate や oxyiodide は 検出されていない.したがってどのよらな反応過程を経 て, 石英が侵蝕され, その結果 $\mathrm{SiO}_{2}$ の結晶が生成される かまだ不明の点が多い。しかし反応により $\mathrm{SiI}_{4}$ が生成さ れ, その結果 $\mathrm{Si}$ が電極のタングステン上に付着すること が，ランプの発光スペクトルの観察および電極タングステ ンのエレクトロンプローブマイクロアナライザーによる分 析で示されている ${ }^{14)}$. 電極上に付着した Si はタングステ
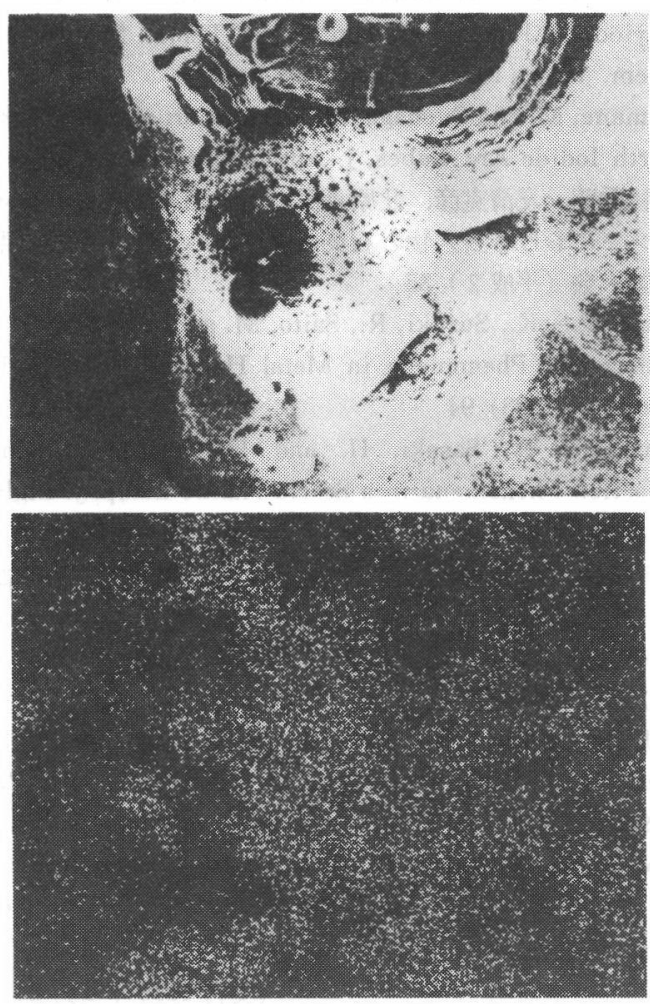

図 4 メタルハライドランプの電極変形

(a) コイルに形成された突起物

(b) EPMA 分析により検出された $\mathrm{Si}$
ンと合金をつくり，融点が低下するため，しばしば電極タ ングステン先端の形状変化をひを起とす. 図 4 にその一例 を示す. 電極のタングステンコイル上に突起物が形成さ れ，Si が検出されている ${ }^{19)}$. とのよらな電極変形は当然 なととながら，ランプの始動不良，ランプ電圧の上昇，管 壁黒化をひを起とし，短寿命となる.

また，Na-Scのよら化物を封入したランプにおいて， 電子放射物質として $\mathrm{ThO}_{2}$ を使用すると， $\mathrm{ThO}_{2}$ が $\mathrm{ScI}_{3}$ と 反応して $\mathrm{ThI}_{4}$ が生成され, 結果として電極先端の変形を ひき起てすととが示されており ${ }^{20)}, \mathrm{ThI}_{4}$ と石英との反応 に原因している.

\section{4 金属材料}

金属材料では，先に述べた金属とガラス・セラミックス との封着・接着時のぬれの問題で表面との関係が深い. ま た主要な光源材料であるタングステンでは, 高温での変形 抵抗性（ノンサグ性）の改善のため, 線の軸方向に長く伸 び，かつ互いにインタロックした大きな再結晶組織をつく るように, ドープ剂と呼ばれる微量の不純物 $\left(\mathrm{K}_{2} \mathrm{O}-\mathrm{SiO}_{2}-\right.$ $\left.\mathrm{Al}_{2} \mathrm{O}_{3}\right)$ を添加する. これらの不純物の結晶粒界での拡散 がノンサグ組織の形成と関係する ${ }^{21,22)}$. タングステンフィ ラメントを用いた光源が複写機や自動車に使用されるとと が多くなり, 而振性の向上に対する要求が強い. さらに緻 密な粒界の制御が求められる.

スパッタリング現象は, 放電を利用するランプ, すなわ ち蛍光ランプから HID ランプまですべてにおいて見られ る現象である. 蛍光ランプの電極材料の管壁への飛散, HID ランプでの電極のタングステンの飛散などである. スパッタリングは，加速された正イオンの衝突により，固 体表面の原子がたたき出される現象である，との現象で重 要な量はスパッタリング率, すなわち入射粒子 1 個当り固 体から放出される原子（または分子）の数である.スパッ タリング率は, 衝突する粒子の種類, 固体の種類や状態に より変化し，物質固有の量でない，スパッタリングは, 照 射イオンの加速電圧がある值以下では生じないしをい值が

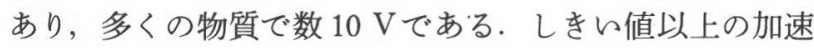
電圧に対しては，スパッタリング率は単調増加する．スパ ッタリンング率は古くから測定されており, $400 \mathrm{eV}$ に加 速した $\mathrm{He}, \mathrm{Ne}, \mathrm{Ar}, \mathrm{Kr}, \mathrm{Xe}$ などの希ガスイオンを各種 金属に衝突させたときの值が報告されている。以上のスパ ッタリング現象に関しては, 優れた成書 ${ }^{23)}$ が刊行されてい る.

\section{5 ゲッタ}

ゲッタはランプに欠くととができない部品である．白熱 電球では管内に水分が存在すると，下記のようないわゆる water cycle によってタングステンフィラメントが損耗す る.

$$
\begin{aligned}
& 3 \mathrm{H}_{2} \mathrm{O}=3 / 2 \mathrm{O}_{2}+3 \mathrm{H}_{2} \\
& 3 / 2 \mathrm{O}_{2}+\mathrm{W}=\mathrm{WO}_{3} \\
& 3 \mathrm{H}_{2}+\mathrm{WO}_{3}=\mathrm{W}+3 \mathrm{H}_{2} \mathrm{O}
\end{aligned}
$$

この水分を除去するため, ゲッタとして赤リンが使われ 
る. また水素を吸収するためには， $\mathrm{Zr}$ パウダが 400 500 ${ }^{\circ} \mathrm{C}$ の温度のととろに塗布される，Zr ゲッタの場合，表面 に吸着した水素を金属内部に拡散させるために上記動作温 度が必要となる。メタルハライドランプでは，外管に $\mathrm{Zr}-\mathrm{Al}$ 合金ゲッタ ${ }^{24)}$ が使用されている。乙のゲッタは $\mathrm{Zr}$ ゲッタより作用が優れており，最適動作温度は 350〜 450 ${ }^{\circ} \mathrm{C}$ である. メタルハライドランプの発光管内に不純ガス として水素が存在すると，ランプ点灯時の再点孤電圧が高 くなり，始動不良をひを起てすが，乙の水素はランプ点灯 とともに発光管材料の石英を透過し，外管に放出される. この水素を吸収し，外管内の水素分圧を出来るだけ低くし て，水素が透過しやすくするととが必要である.ゲッタの 用途の多様化とともに，低温活性・低温動作の要求がでて おり，新しく $\mathrm{Zr}-\mathrm{V}-\mathrm{Fe}$ 合金ゲッタが開発され ${ }^{25)}$, さらに ゲッタの使用可能範井が広がった.

\section{3. まとめ}

ガラス・セラミックス，蛍光体，電子放射材料，金属材 料，封人材料，ゲッタなどの光源材料の表面・界面現象に ついて述べた。 ランプにおいて表面・界面が関与する現象 が多く，かつランプの性能に及ぼす影響も大きいととに気 づくであろ5．電球蛍光ランプ，コンパクト蛍光灯などで は管壁負荷が一般の蛍光ランプより高く，その結果材料に 対する要求もきびしくなっている. さらに情報機器用光源 にハロゲンランプ，蛍光ランプが利用されてきて，輝度の バラッキ, 端部黒化, 寿命など従来の一般照明では許谷さ れていた性能がそのままでは使えないてともあらわれてき た.メタルハライドランプが液晶プロジェクタ一の光源に 使われると，発光管の内壁に付着するよら化物や管壁の白 濁がそのままスクリーンの輝度むらとしてあらわれるとい ら問題はその一例である。乙れらの問題解決には表面・界 面の現象解明が必須であるととは言らまでもない，表面・ 界面の現象は種々の要因が入りまじって複雑であるが，幸 いに最近の表面解析機器の発展により, 解析が種々の手段 で行えるよらになった．光源材料研究者の今後の活躍に期 待する.

\section{参 考 文 献}

(1) ジョンF.オハンロン（野田，斉藤，奥谷訳）：真空技術マ ニュアル, 産業図書 (昭 58)

(2) 伴 一成：ランプ用ガラス (石英ガラス), 照学誌, 69-1 (昭 60) 8

(3) 作花, 境野, 高橋編：ガラスハンドブック, 朝倉畫店（昭 57)

(4) 山本 登: 高压ナトリウムランプ用ソルダガラス, 照学 誌, 64-3 (昭 55) 127

（5）大森隆雄: 最近の照明用ガラスの進歩, 照学誌, 69-1（昭 60) 6
（6）谷水伸吉：けレ光ランプ用けレ光体, 照学誌, 64-3（昭 55) 118

(7) 照明学会セラミック材料研究調查委員会：セラミック材料 研究調查報告書, JIER-010, （昭 63）

(8) Waymouth, J. F. ; Electric Discharge Lamps, The M. I. T. Press, Cambridge (1971)

(9) 渡部勁二，斉藤正人；バリウムタングステート・エミッタ の熱電子放射とその水銀ランプに及ばす影響, 照学誌, 62 -4 (昭 53) 175

(10) 井上昭浩, 小川一行; 放電灯の始動特性, 東芝レビュ一, 29-9（昭 49） 760

(11) 弘; $\mathrm{Sc}, \mathrm{Th}, \mathrm{Na}$ のよう化物を封入したメタルハラ イドランプの始動現象, 照学誌61-4（昭 52）218

(12) 椠見 弘; よ5化ナトリウム，水銀および諸気体の複合吸 着によるタングステンの仕事関数の変化, 新日本電気技 報, 10 (昭 50) 18

(13) Tsuchihashi, M., Watanabe, K., Saito, M. and Suzuki, R. ; Improvement of Lumen Maintenance in a Retrofit $\mathrm{Sc}-\mathrm{Na}$ Metal Halide Lamp, The ECS, Fall Meeting, Extended Abstracts, 80-2 (1980) 1469

(14) Speros, D. M., Datta, R. K. and Lynch, D. A. ; Chemical Reactivity in Halide Discharges : Effects of Condensed Phases and Common Components, J. Electrochem Soc. 128-4 (1981) 778

(15) Fischer, E., Kaiser, R. and Niemann, U. ; Thermochemical Data of Scandium Halides Evaluated from Vapor Pressure Measurements and Reactions with Quartz, 5th Int. Symp. on the Science and Techn. of Light Sources, York-England (1989)

(16) Work, D. E. ; Preliminary Investigations of Scandium Oxyiodies, Proc. Symp. on High. Temp. Metal Halide Chem. 78-1 (1978) 133

(17) Yamane, M. and Suenaga, M. ; Transport of Silica in Rare Earth Iodide Arc Tubes, J. Appl. Phys., 54-1 (1983) 107

(18) 大村秀明, 友清克彦, 北原良樹; 希上類系メタルハライド ランプにおける封入物と石英ガラスとの反応，平成 2 照学 全国大会（平成 2 ） 35

(19) Watanabe, K., Suzuki, R., Saito, M. and Tsuchihashi, M. ; Electrocle Phenomena in Metal Halide Lamps, J. IES. October (1983) 94

(20) Ishigami, T., Sasaki, H. and Honma, M. ; Chemical Reaction Phenomena in a Sc-Na Halide Lamp, J. Light \& Vis. Env. 7-1 (1983) 1

(21) 辻川正弘; 光源材料関係の諸問題 : 光源用金属, 照学誌, 64-3（昭 55） 115

(22) 山崎 修; ランプ用タングステン線, 照学誌, 69-1（昭 60) 20

(23) 金原 粲; スパッタリング現象, 東京大学出版会 (昭 59)

(24) Rabusin, E. ; Getters for Lamps, SAES Getters S. P. A., (1982)

(25) Boffito, C., Ferrario, B., della Porta, P. and Rosai, L.; A Nonevaporable Low Temperature Activatable Getter Material, J. Vac. Sci. Technol., 18-3 (1981) 1117

(受付 1990 年 6 月 23 日) 